\title{
The multinationality and performance relationship: revisiting the literature and exploring the implications
}

Article

Accepted Version

Creative Commons: Attribution-Noncommercial-No Derivative Works 4.0

Nguyen, Q. T.K. and Kim, S. (2020) The multinationality and performance relationship: revisiting the literature and exploring the implications. International Business Review, 29 (2). 101670. ISSN 0969-5931 doi:

https://doi.org/10.1016/j.ibusrev.2020.101670 Available at https://centaur.reading.ac.uk/88578/

It is advisable to refer to the publisher's version if you intend to cite from the work. See Guidance on citing.

To link to this article DOI: http://dx.doi.org/10.1016/j.ibusrev.2020.101670

Publisher: Elsevier

All outputs in CentAUR are protected by Intellectual Property Rights law, including copyright law. Copyright and IPR is retained by the creators or other copyright holders. Terms and conditions for use of this material are defined in the End User Agreement.

www.reading.ac.uk/centaur 
Central Archive at the University of Reading

Reading's research outputs online 
THE MULTINATIONALITY AND PERFORMANCE RELATIONSHIP:

REVISITING THE LITERATURE AND EXPLORING THE IMPLICATIONS

Dr. Quyen T.K. Nguyen (Ph.D.) (Corresponding Author)

International Business and Strategy

Henley Business School

University of Reading

Whiteknights Campus, Reading, Berkshire, RG6 6AH, the United Kingdom

E-mail: t.k.q.nguyen@ henley.ac.uk

Dr. Sylvia Kim (DBA)

Fresno Pacific University

1717 S. Chestnut Ave.

Fresno, CA 93702, the United States of America

Email: sylvia.kim@fresno.edu 
THE MULTINATIONALITY AND PERFORMANCE RELATIONSHIP:

\title{
REVISITING THE LITERATURE AND EXPLORING THE IMPLICATIONS
}

\begin{abstract}
The relationship between the degree of multinationality $(\mathrm{M})$ and performance $(\mathrm{P})$ of multinational enterprises (MNEs) is a central research question in the literatures of international business, management, strategy, and finance in the past 50 years. However, theoretical foundations and empirical findings are far from being in unison. Thus, it is necessary to conduct a critical review. We offer new insights by combining international business, accounting and finance perspectives in our review. We examine 160 articles in 43 scholarly journals and classic books published during the period 1960-2017. We use an inductive approach and a qualitative content analysis methodology. We review the extant literature and identify eight key inconsistencies, which may cause ambiguity in the findings. These include the deficiency of direct evidence to substantiate the arguments of benefits and costs of internationalization on performance, inherent limitations in the conceptualization and measurements of M, P, intangible assets, geographic research contexts and methodologies. We make eight recommendations for future research to address these inconsistencies.
\end{abstract}

Key words: multinationality (M); performance (P); M-P relationships; accounting perspectives (IAS38; IFRS8 and FASB131). 
THE MULTINATIONALITY AND PERFORMANCE RELATIONSHIP:

\section{REVISITING THE LITERATURE AND EXPLORING THE IMPLICATIONS}

\section{Introduction}

In the past 50 years, the effect of multinationality $(\mathrm{M})$ on firm performance $(\mathrm{P})$ is a central research question in the literatures of international business (IB), strategy, management, and finance. Yet, the existing academic discussion lacks a common theoretical ground given that it has examined the phenomenon from a wide variety of theoretical perspectives. The empirical research has produced mixed results with different functional forms, ranging from linear, non-linear and those with no relationship (Li, 2007). These inconsistent results have prompted several criticisms of this literature (Hennart, 2007; 2011; Verbeke \& Brugman, 2009; Verbeke \& Foroontan, 2012).

The development of the M-P literature has accelerated to a point which calls for a systematic review and critical assessment. A clearer understanding of the phenomenon is needed in order to draw more objective conclusions. We aim to address three closely interrelated research questions:

(1) How has the M-P literature been theorized and what are the main empirical findings to date?

(2) Are there any inconsistencies in the literature?

(3) How can these inconsistencies be addressed in future research?

We use the inductive methodology and the qualitative content analysis in our review of 160 articles in 43 journals and classic books published between 1960 (starting with the seminal work of Hymer, 1960 on foreign direct investment (FDI) of firms) and 2017. We hope that 
our study extends previous literature review articles by analyzing what have not been addressed and/or what have not been well-addressed.

Our study is distinct from previous review articles in several aspects. First, we present the state of the art of M-P relationship research in our systematic and disciplined review. We find that the literature has used a wide range of theories. The variety in the theoretical premises may provide a nuanced understanding of the phenomenon. However, it may make the literature more ambiguous because it becomes difficult to link the results to any particular theory and to establish which theory is confirmed, refused or extended (Kirca, Hult, Roth, Cavusgil, Perry, Akdeniz, Deligonul, Mena, Pollitte, Hoppner, Miller, \& White, 2011).

Second, we combine theoretical perspectives from international business, accounting and finance in our review and critical analysis of the extant literature and make suggestions for future research. We show the necessity to use this approach because in this way, we hope to offer new insights by looking at "old issues" with "new lens". We find that many studies provide neither direct measurements nor direct empirical evidence for theoretical arguments of the benefits and costs of internationalization on performance. They predominantly focus on validating the functional forms of the M-P relationship and refer to the hypothesized benefits and costs of internationalization in the conclusions. Furthermore, we use accounting perspectives to analyze the inconsistencies between conceptualization and operationalization of $\mathrm{M}, \mathrm{P}$, and firm-specific intangible assets. Our study also reveals that there is a deficiency of studies distinguishing performance of home country operations from performance of international operations of foreign subsidiaries as a result of internationalization through foreign direct investment (FDI) activities. The M-P literature has been examined in a rather limited geographical context, with many studies using the U.S. firms' datasets. There is also a lack of cross-country comparative analysis. In terms of methodology, the M-P research is 
largely in favor of quantitative approach. Studies using qualitative and mixed methods are non-existent, and thus constrain the in-depth understanding of the phenomenon. These points are elaborated in more detail in the section of findings and discussion.

Third, we make eight suggestions for future research to study the topic in a more refined and different way than in the past (LePine \& Wilcox-King, 2010). They are elaborated in more detail in the section of suggestions for future search. These include

(1) FSAs determine firm performance, not multinationality per se.

(2) Examine the use of retained earnings to finance FSAs development.

(3) Move away from validating the functional form of the M-P relationship and focus on showing direct evidence of the disaggregated benefits and costs of internationalization on performance.

(4) Use geographic segment measurements instead of traditional measurements of multinationality.

(5) Use value-based performance measurements.

(6) Distinguish the effects of performance of home country operations from international operations by examining return on home assets (ROHA) and return on foreign assets (ROFA) separately.

(7) Include finance factors (e.g. risk and return) in future research design.

(8) Increase the diversity of geographic research settings and data samples, and cross-country comparative analysis.

\section{Methodology}

\subsection{Focus of study}


A literature review provides an overview and evaluation of the research area (Jormanainen \& Koveshnikov, 2012). It is important to examine what and how theoretical concepts and approaches are applied to explain the M-P relationship in order to analyze the main results as well as inconsistencies in the existing literature. To achieve our objective, we critically assess M-P studies published across disciplines and domains and consolidate findings because there is a lack of integration in the existing literature (Kirca, Hult, Deligonul, Perry \& Cavusgil, 2012; Kirca, Roth, Hult, \& Cavusgil, 2012). Overall, we aim to identify potential inconsistencies and gaps in the literature and suggest several future research avenues.

\subsection{Methodological approach}

To examine our research questions, we follow the inductive approach and the qualitative content analysis method, which is defined as a qualitative method to interpret meaning from the content of the articles (Duriau, Reger \& Pfarrer, 2007; Welch, Piekkari, Plakoyiannaki \& Paavilainen-Mantymaki, 2011). The inductive nature guides us to examine the state of art of the field in the peer-review academic journals and classic books because they are considered as the primary source of knowledge. The qualitative content analysis offers the possibility to interactive conceptual development and a holistic interpretation of a text (Welch et al., 2011). This methodology allows us to examine "how" this phenomenon has been addressed and "what" are the main findings to date. This methodology has been used effectively in previous literature review article by Jormanainen \& Kovesnikov (2012).

\subsection{Definition of concepts, selection of databases and journals}

The first methodological step is to define concepts which provide a clear description of the research focus (Jormanainen \& Kovesnikov, 2012). To conceptually justify our search and selection of texts for our review, we focus on the M-P research in the context of the 
multinational enterprise (MNE). According to Rugman (1981), an MNE is defined as a firm that internationalizes by engaging in FDI activities and establishing a network of foreign subsidiaries rather than exporting or licensing and has the ratio of foreign sales over total sales of at least $10 \%$ and three foreign subsidiaries. The threshold of 10 percent comes from the accounting standards (IFRS8-Operating Segments (IFRS website, 2018) and the US GAAP FASB131-Disclosures about Segments of an Enterprise and Related Information (US GAAP website, 2018). Thus, research on the relationship between internationalization (I) and performance $(\mathrm{P})$ by exporting of small and medium sized enterprises (SMEs), international new ventures (INVs) and born global firms, and the internationalization of the top management team (TMT) is out of the scope of our review. In this way, our search approach differs from previous review papers which include empirical studies of different types of firms with numerous internationalization modes.

The second methodological step is to define database for the analysis (Duriau et al., 2007). We follow several strategies used in Kirca et al. (2011) to identify the highest possible number of studies testing the M-P relationship in the MNE context. First, we use major scholarly electronic databases, such as Business Source Complete, Proquest ABI/Inform, ScienceDirect, and JSTOR to search for articles on the performance implications of internationalization of the MNE. The search terms include multinationality, the degree of multinationality, internationalization, the degree of internationalization, international diversification, geographic diversification, international expansion, and international market diversification. These terms tend to be used interchangeably although they are not synonyms (Verbeke \& Brugman, 2009). Second, we use the United Kingdom-based Chartered Association Business School (CABS) Academic Journal Guide 2015 which provides a list of journals and information on journal ranking with impact factors by the ISI Web of Knowledge database (CABS website, 2019). Based on the list of CABS-ranked journals, we 
perform a manual search of articles in these journals across the disciplines of IB, management, strategy, marketing, finance, financial management and accounting. Third, we consult reference sections of all previous review articles (Hitt, Tihanyi, Miller \& Connelly, 2006; Li, 2007; Matysiak \& Bausch, 2012; Osterle \& Richta, 2013), meta-analytic articles (Bausch \& Krist, 2007; Geleilate, Magnusson, Parente \& Alvarado-Vargas, 2016; Kirca et al., 2011; Kirca et al., 2012; Kirca et al., 2012; Marano, Arregle, Hitt, Spadafora \& van Essen. 2016; Yang \& Driffield, 2012) and conceptual articles (Glaum \& Oesterle, 2007; Hennart, 2007, 2011; Verbeke \& Brugman, 2009; Verbeke \& Forootan, 2012). This careful process helps us search and find relevant articles for our review.

\subsection{Selection of texts for analysis}

After identifying databases and journals, our next step is to select texts for our review (Duriau et al., 2007). We include published full-length research articles because they are subject to a rigorous peer-review process (Jormanainen \& Kovesnikov, 2012). We also examine a number of classic seminal books to gain a more grounded understanding because this approach has been used in previous literature review study (Cavanagh et al., 2017). However, we exclude unpublished thesis, dissertations, working papers, conference papers and periodicals (Podsakoff, Makenzie, Bachrach \& Podsakoff, 2005). The period coverage ranges from the publication of Hymer work (1960, published in 1976) to 2017.

The final step of our review involves selecting the articles shown in the databases and journals (Jormanainen \& Kovesnikov, 2012). We go through all articles by reading carefully the title, abstract, key words, introduction, conclusion and journal outlets to determine the suitability and potential to inform our study. Once we select an article in this manner, we evaluate it against a set of criteria for inclusion into the study. The criteria are: (1) the article 
focuses on MNEs; (2) directly and explicitly examines the M-P relationship and (3) is peerreviewed for journal articles. Upon completion of the literature retrieval procedures, we obtain 153 articles (128 empirical articles and 25 conceptual and literature review articles) in 43 journals and seven classic books, which make a total sample of 160 studies.

\subsection{Analytical approach}

First, we follow the approach in the study by Jormanainen \& Koveshnikov (2012). Specifically, Welch et al. (2011) suggest examining the qualitative aspects of these articles. The focus is the manifest content of each article (Suddaby \& Greenwood, 2005). We proceed by reading the full contents of these articles and documenting all necessary information in an excel spreadsheet file. These include identification number, authors, title, dimensions of multinationality and performance, methodology (sampling and analytical method) and main findings. While we analyze the articles along these dimensions, we summarize our findings in several tables categorizing the total set of articles/ books according to their distribution across journals, geographic scope and methodological approach which help us proceed systematically (Miles \& Huberman, 1994).

Second, we analyze the latent content of each article in more detail (Suddaby \& Greenwood, 2005). This procedure ensures that the articles make direct and explicit contribution to the MP literature. We read each article and focus on theoretical perspectives adopted, and conclusions derived. We analyze our records and organize them into distinct conceptual and empirical findings. This allows us to enrich our analysis with multiple interpretations and to achieve subjective understanding (Welch et al., 2011).

Third, we interpret the results according to three main areas: (1) the critical findings; (2) the methodological approaches and the geographic scope; (3) the inconsistencies in the 
theorizing and operationalizing concerning the M-P phenomenon, on which we suggest avenues for their clarification in future research. We also analyze the publication pattern of the research in terms of its distribution across journals (Jormanainen \& Kovesnikov, 2012). Table 1 reports featured articles classified by publication outlets.

\section{Insert Table 1 about here}

We aim to provide an overview of the state of the field itself by surveying theoretical underpinnings and empirical findings and summarize the contributions in the extant literature. The content analysis of the selected articles also allows us to identify gaps in the literature. We analyze what and how theoretical concepts and approaches have been utilized, and what and how empirics match or mismatch theoretical arguments.

\section{A review of the literature}

In this section, we provide a brief summary of theories and frameworks used in the extant M$\mathrm{P}$ literature and theoretical issues which have been subject to debate. Next, we offer our critical analysis and assessment of the state of the theoretical literature.

\subsection{Theoretical literature review}

The literature has used numerous theoretical perspectives to prescribe the impacts of $\mathrm{M}$ on $\mathrm{P}$. The key theories which underpin the M-P literature include internalization theory (Buckley \& Casson, 1976; Hennart, 1982; Rugman, 1981); Dunning's eclectic paradigm (Dunning, 1985); the resource-based view of the firm (Barney, 1991; Teece, Pisano \& Shuen, 1997; Wernerfelt, 1984); risk reduction by international diversification (Rugman, 1976); the liability of internationalization (Eden \& Miller, 2001; Hymer, 1960; Zaheer, 1995); incremental internationalization process and experiential learning (Johanson \& Vahlne, 1997; Johanson \& Vahlne, 2009); organizational evolution and organizational learning (Chandler, 
1962; Contractor, Kundu \& Hsu, 2003; Lu \& Beamish, 2004; Sullivan, 1994a, b; Tushman \& Romanelli, 1985); the portfolio theory (Markowitz, 1952; Cohen, 1972; Severn \& Laurence, 1974); the real option theory (Buckley \& Casson, 1998; Buckley, Casson \& Gulamhussen, 2002; Chi \& McGuire, 1996; Kogut, 1991; Kogut \& Kulatilaka, 1994; Tong \& Reuer, 2007; Li \& Rugman, 2007; Li, 2007); the operational flexibility (Allen \& Pantzalis, 1996; Anand, Oriani \& Vassolo, 2007; Fisch, 2008; Fisch \& Zschoche, 2011a, 2012; Lee \& Makhija, 2009; Kogut \& Kulatilaka, 1994); downside risk (Belderbos, Tong, Wu, 2014; Tan \& Peng, 2003), the net effect of the degree of multinationality on the value-relevance of corporate real option portfolios (Aabo, Pantzalis \& Park, 2016). We prepare a summary table of key arguments and implications of each of these theories on the M-P relationship (see Appendix 1).

\subsubsection{A summary of the debate on theoretical issues}

Many different results of empirical studies have caused skeptical opinions on the M-P research. Some scholars criticize the theories which the M-P empirical literature is based on. Hennart's (2007) criticism is that although M-P studies have used a diversity of theoretical approaches, MNE theories do not imply direct and generalizable relationship between $\mathrm{M}$ and P. Hennart (2007) argues that M-P studies generally predict the relationship based on various theories - theory of portfolio diversification (Kim, Hwang \& Burgers, 1993; Reeb et al., 1998), the resource-based view (Kotabe, Srinivasan \& Aulakh, 2002), and the organizational learning theory but the findings of this literature have been significantly varied.

Being internationally diversified is assumed to increase profitability because: (i) it makes it possible for exploit economies of scale (Contractor et al., 2003; Hitt et al., 1997); (ii) it provides better and more flexible access to resources (Contractor et al., 2003); and (iii) it allows for more organizational learning (Contractor et al., 2003; Hitt et al., 1997; Kim et al., 
1993). However, Hennart (2007) argues that none of these make a strong case for a robust relationship between multinationality and performance.

Instead, Hennart (2011) argues that the degree of multinationality is explained by a firm's choice between internally coordinating the stages of its value chain and letting external market decide them. Thus, there is no relationship between multinationality and profitability but there is only a wrong or right decision on the degree of internationalization compared to the optimum.

On the other hand, Verbeke \& Brugman (2009) maintain that the M-P relationship is not correctly theorized. From the perspective of internalization theory, performance of a firm is primarily dependent on its FSAs, instead of its degree of multinationality. Verbeke \& Forootan (2012) argue that ignoring the fact that FSAs are the main factors for the firm's internationalization strategies and related impacts on performance is a serious problem in M$\mathrm{P}$ research.

\subsubsection{Our analysis on theoretical issues}

Our analysis offers three key findings. First, our survey of the literature reveals that due to its implications for several disciplines, the M-P relationship has been extensively examined through a variety of theoretical lenses. Additionally, numerous studies tend to use more than

one theory in developing hypotheses. As a result, the literature is characterized by conceptual models which incorporate different theoretical perspectives to argue for the benefits and costs of multinationality on firm's overall performance. However, this approach has been criticized by Kirca et al. (2011) because it may cause more confusion than clarification. 
Second, organizational learning theory has been widely used in developing U-curve, inverted U-curve and S-curve models (Hitt et al., 1997; Gomes \& Ramaswamy, 1999; Contractor et al., 2003; Lu \& Beamish, 2004). Yet, it remains unclear what and how firms have learned and what are the mechanisms of organizational learning which lead to higher performance.

Third, our study finds that the number of empirical studies which examines FSAs as a determinant of firm performance is much smaller than those testing $\mathrm{M}$ as a determinant of $\mathrm{P}$. Rugman (1981) and Morck \& Yeung (1991) find that FSAs are more important for firm performance than the degree of multinationality. An insufficient attention to FSAs as a determining factor to firm performance is problematic given that the important role of FSAs, such as R\&D is found to be positively and partially associated with both internationalization and performance (Buckley \& Casson, 1976; Li, 2007; Verbeke \& Brugman, 2009).

\subsection{Empirical literature review}

The literature on the M-P relationship over 50 years is quite extensive but empirical findings are far from being in unison. Empirical research has found inconclusive and even contradicting relationships between $\mathrm{M}$ and $\mathrm{P}$. These include a positive linear, a negative linear and a non-linear relationship. Depending on disciplines, the focus in the M-P research varies greatly. Studies published in IB and strategic management journals tend to examine non-linear relationships with different shapes whereas those published in accounting and finance journals investigate positive and negative linear relationships.

\subsubsection{Positive M-P relationship}

The positive linear model has been found to support the benefits of international expansion mainly based on internalization theory and the resource-based view of the firm. Internalization theory argues that a firm maximizes profit when it develops and exploits its 
FSAs by internalizing in the face of market imperfections (Buckley \& Casson, 1976; Hitt et al., 2006; Li, 2007; Rugman, 1981; Rugman et al., 1985).

The M-P literature discusses other benefits of internationalization on firm performance. These include economies of scale and scope by leveraging resources and capabilities across geographic markets (Buckley \& Casson, 1979). Furthermore, Rugman (1990) argues that a network of production units also enables plant-level economies of scale owing to specialization. Specialization enables MNEs to profit from the best matches between FSAs available in their internal network and country-specific advantages (CSAs) in various locations.

The literature also outlines the benefits of risk reduction of international diversification (Rugman, 1976). Furthermore, MNEs gain operational flexibility by having a portfolio of production sites (Contractor, 2012; Fisch \& Zschoche, 2011a, 2012; Lee \& Makhija, 2009). Aabo et al. (2016) adopt a finance perspective to examine the net effect of multinationality on the value that firms derive from their real options, meaning whether the relationship between stock returns and changes in return volatility varies with multinationality. Their results indicate that multinationality indeed acts as a real option facilitator.

\subsubsection{Our analysis on positive M-P relationship}

While the empirical evidence may support the positive effects of internationalization on firm performance, they do not fully explain the dynamic complexity of internationalization (Cardinal et al., 2011). The underlying assumptions of the positive linear M-P relationship imply that international opportunities are unlimited and that MNE managers possess unlimited capacities to handle the increasing complexity and challenges from international expansion effectively and efficiently. However, these assumptions are unrealistic. The 
benefits of international expansion through location advantages, growth opportunity, and economies of scale and scope are not inexhaustible (Cuervo-Cazurra, Maloney \& Manrakhan, 2007). Managers of MNEs cannot always maintain the maximum level of capacities even with enhanced organizational structure and other managerial improvements. Instead, the increasing complexity and challenges of international operations may cause a negative effect on MNEs' performance when MNE managers experience bounded rationality and bounded reliability problems in dealing with them (Verbeke, 2013).

\subsubsection{Negative M-P Relationship}

The negative M-P model emphasizes more on the incremental costs of doing business internationally because of the liability of foreignness (Eden \& Miller, 2001; Hymer, 1960; Zaheer, 1995) and the liability of newness (Lu \& Beamish, 2004; Stinchcombe, 1965). Hymer (1960) is the first to identify the cost of doing business abroad. The adaptation to the new environment can be interpreted as an organizational learning process. Firms need to develop new routines that require substantial investments of time, monies and efforts (Diffeld, 2017). In addition, the problems of bounded rationality and bounded reliability (Verbeke, 2013) may affect management's ability to properly handle the increased complexity from international expansion, which in turn can negatively affect MNEs' profitability (Guisinger, 2001; Kostova \& Zaheer, 1999; Sundaram \& Black, 1992). It is finance scholars that often find the negative impacts of internationalization on firm

performance ( $\mathrm{Li}, 2007)$. Market values of MNEs are found to be discounted compared to similar domestic operations (Click \& Harrison, 2000; Denis, Denis \& Yost, 2002).

\subsubsection{Our analysis on negative M-P relationship}


According to Verbeke (2009), because of bounded rationality, MNE headquarter managers often overestimate the international profit potential of their firms' FSAs, and underestimate the efforts required to penetrate and operate effectively and efficiently in international markets. On the other hand, the negative M-P model appears to underestimate subsidiary managers' capabilities to overcome the liability of foreignness. We argue that compared to headquarter managers, subsidiary managers have local knowledge of host country business environments, and they manage to develop new resources and capabilities which enable them to tackle challenges of local operations (Birkinshaw, 1996, 1997; Rugman \& Verbeke, 2001; Nguyen \& Rugman, 2015 a,b). The subsidiary management literature documents that subsidiaries use autonomy granted by their parent firms and undertake entrepreneurial initiatives to formulate strategies which respond to local market conditions, accommodate consumer preferences and build local legitimacy. Thus, this strategy helps to reduce the problems of bounded rationality and bounded reliability of headquarter managers in managing a network of foreign subsidiaries and mitigate any potential negative impacts of internationalization on performance.

\subsubsection{Non-linear M-P Relationships}

A number of studies which build upon the organizational learning theory to examine samples of firms in early internationalization stage find a U-curve M-P relationship, with a decreasing performance in the first stage due to the liability of foreignness and an increasing performance after successful learning process in the second stage (Capar \& Kotabe, 2003; Ruigrok \& Wagner, 2003). Research which examines MNEs in advanced internationalization stage detects an inverted U-curve (Hitt, Hoskisson \& Kim, 1997; Gomes \& Ramaswamy, 1999). On the other hand, several studies adopt the theoretical perspective of incremental internationalization to argue that the M-P takes on an inverted J-curve (Daniels \& Bracker, 
1989; Geringer, Beamish \& da Costa, 1989). However, several limitations have been identified in the underlying assumptions of these models (Cardinal et al., 2011).

Contractor et al. (2003) develop the horizontal S-curve or three-stage paradigm of the M-P relationship. The 3-stage paradigm is supposed to provide a more dynamic, longitudinal, or evolutionary explanation of the effect of three sequential stages which firms go through while they are expanding internationally (Bae, Park \& Wang, 2008; Contractor et al., 2003; Kudina, Rugman \& Yip, 2009; Lu \& Beamish, 2004; Oh \& Contractor, 2014; Rugman \& Oh, 2010; Ruigrok, Amann \& Wagner, 2007; Thomas \& Eden, 2004). The three-stage paradigm tries to reconcile the various empirical findings previously described, where MNEs suffer financial performance at low multinationality levels, performance goes up during longer, moderate multinationality levels, and performance goes down again at extremely high multinationality levels. As a whole and over the considerable middle range of expansion, MNEs enjoy net positive benefits from internationalization, that supports the idea that international expansion is good for firms' performance and does indeed result in net positive benefits to MNEs (Contractor, 2007).

Lu \& Beamish (2004) develop a theoretical framework for an S-curve relationship between $\mathrm{M}$ and $\mathrm{P}$ which includes both benefits and costs of geographic expansion over three phases of internationalization. They predict that this relationship is positively moderated by the level of a firm's intangible assets ( $R \& D$ intensity and marketing intensity). They test these hypotheses using a sample of 1,489 Japanese firms from 1986 to 1997, which includes 1,059 firms that have at least some FDI. They use two measures of firm performance - one accounting based return on assets (ROA) and the other market-based Tobin's Q. They find support for their hypotheses. 
Berry \& Kaul (2016) replicate the S-curve relationship reported in Lu \& Beamish (2004). Using a longitudinal and comprehensive database on the population of U.S. MNEs from 1989 to 2007 collected by the US Bureau of Economic Analysis (BEA) (BEA website, 2019), they find no evidence of an S-curve relationship, nor do they see a moderating effect of intangible assets. Similarly, Abdi \& Aulakh (2018) assess the theoretical underpinnings and associated empirical findings of the three-stage sigmoid-curve relationship between degree of internationalization (DOI) and performance by re-examining the empirical results reported in Lu \& Beamish (2004). They complement this by conducting their own analysis of 23,474 observations of 2,620 US manufacturing firms over the period 1976-2008 and account for self-selection of firms into different degrees of internationalization by using a generalized propensity score estimator. Both sets of results show that the relationship between DOI and performance conforms to a mostly negative sigmoid curve and does not support the threestage theorization.

On the other hand, Ruigrok et al. (2007) find an inverted S-curve for the M-P relationship using a sample of Swiss firms. Similarly, Chiang \& Yu (2005) find an inverted S-curve for a sample of Taiwanese firms for the period of 1998-2002.

Ferraris, Bresciani \& Del Giudice (2016) propose a four-stage model of M-P relationship and empirically test it using a dataset of the 391 MNEs in the Fortune Global 500 firms for the year 2012. They find an inverted M-curve of the M-P relationship. Moreover, by comparing home region and host region-oriented firms (Rugman \& Verbeke, 2004), they find how the form of this relationship is different, by highlighting an M-curve relationship for host regionoriented firms. 
On the other hand, it is noted that the M-curve and W-curve models of internationalization and performance relationship have been developed mostly using export data and the datasets of international new ventures (INVs) or born-global firms, family business SMEs, but not MNEs with FDI activities (Almodóvar, 2012; Almodóvar \& Rugman, 2014; Lee, 2010, 2013; Fernández-Olmos, Gargallo-Castel \& Giner-Bagües, 2016). The M-curve explains internationalization and performance relationships with an increased positive performance in the initial stage followed by the S-curve.

\subsubsection{Our analysis on the non-linear M-P relationships}

Our analysis focuses on the S-curve because there are some inherent limitations in the underlying assumptions of the S-curve. Arguably, it is not always realistic to expect an upward slope after poor performance in the initial international expansion period. There may be a bankruptcy before MNEs turn around and become profitable again. Furthermore, if firms choose to expand into countries that are easier to understand and manage, they may not need to go through the initial downturn. Also, the range restriction of the S-curve and several slope changes across the range of an independent variable present serious statistical issues.

The three studies of Contractor et al. (2003), Berry \& Kaul (2016) and Abdi \& Aulakh (2018) use US firms' datasets to test the S-curve. However, they produce different results. Berry \& Kaul (2016) and Abdi \& Aulakh (2018) find no evidence to support the S-curve advanced by Contractor et al. (2003) and Lu \& Beamish (2004). Our study reveals the complex and dynamic nature of the M-P relationship. The mixed findings prompt us to identify inconsistencies in the literature and propose suggestions to address these inconsistencies in future research. The next section will present our key findings and discussion. 


\section{Findings and discussion}

It is noted that in the sections of conceptualization and measurements of multinationality, performance and intangible assets, we provide first a review on frequently used measurements of $\mathrm{M}, \mathrm{P}$ and intangible assets in the extant literature. Then, we proceed to analyze several inherent limitations of some underlying assumptions of these measurements using international business and/or accounting perspectives. These inconsistencies may lead to mixed empirical results.

\subsection{Limited direct empirical evidence of the benefits and costs of internationalization on the overall performance}

Our analysis: We find that many of the previous studies use the arguments of benefits and costs of internationalization to discuss the impacts on the firm's total overall performance with a prescribed functional form. When it comes to empirical testing, they focus on validating the functional form of the M-P relationship, then draw conclusions which refer to the hypothesized benefits and costs underlying the predictions (Dittfeld, 2017). They provide neither direct measurements nor direct empirical evidence which is explicitly linked to the theoretical arguments for the specific benefits and costs of internationalization on the overall performance outcome.

We find that in the large volume of the M-P literature, the studies by Fisch \& Zschoche (2011b) and Richter (2014) are among few attempts to theorize, measure, and empirically test some types of specific benefits and costs of internationalization. Fisch \& Zschoche (2011b) examine the effects of liabilities of foreignness, economies of scale and multinationality on firm performance. Drawing upon the information cost view of Casson (1999), Fisch \& Zschoche (2011b) develop an information cost model of internationalization to justify an S- 
shape relationship in which liabilities of foreignness and economies of scale exert separate influences on performance. It is assumed that the complexity of collecting and processing information and the associated costs increase with a firm's degree of multinationality.

In the related manner, Richter (2014) argues that it is necessary to shift the focus from overall performance to individual performance aspects, namely, specific benefits and costs arising from different facets of internationalization. She analyzes the effects of economies of scale, multinationality and host market diversity and international organizational decentralization on internal information costs. Although internal information costs decline due to economies of scale in international operations, they are affected by the degree of host country diversity, meaning a growing cultural diversity increases internal information costs per unit.

Richter (2014) measures internal information cost per unit by the administration costs provided in the income statement in firms' annual reports. These cover the management costs, such as personnel costs of directors, and personnel costs of general managers which cannot be assigned directly to production, sales, or R\&D and span different functional organizational areas, costs of accounting, controlling and planning based on the German accounting standards, 255(2) HGB/ Commercial Code, IAS1.99, 1.104, 16.19.

\subsection{Inconsistency between conceptualization and measurements of multinationality}

\subsubsection{Literature review}

The M-P research has used a wide variety of proxies and multi-dimensional constructs to measure multinationality (Hennart, 2011). The scale metrics are measured by the ratio of foreign sales to total sales (FS/TS); the ratio of foreign assets to total assets (FA/TA); the ratio of foreign employees to total employees (FE/TE); and the ratio of overseas subsidiaries to total subsidiaries (OS/TS). The scope metrics include count-based number of foreign 
subsidiaries, and number of countries. The literature also uses other measurements, such as external environment of cultural and institutional diversity of foreign countries; attitudinal attributes of the top management team's international experience and orientation being added to scale and scope metrics to make a composite index (Sullivan, 1994a, b). Other measurements comprise sales-based entropy indices; multiple indicators; a composite index of two or three indicators. A few studies use asset and sales coverage to measure multinationality.

The conceptualization and measurements of multinationality are subject to numerous criticisms (Li, 2007; Hennart, 2011; Rugman \& Oh, 2011). For example, the FS/TS ratio is used to measure to the degree of multinationality; however, this ratio includes exports by parent firms in home countries and sales generated by foreign subsidiaries in host countries. It is difficult to disentangle foreign sales by exporting from parent firms and sales by FDI activities because they reflect two different modes of servicing international markets. Rugman \& Oh (2011) also argue that scope metrics provide simplistic and misleading information on the international activities of the firms because they fail to measure the real scale of internationalization which the firms have achieved from their foreign business activities (Rugman \& Oh, 2011). In contrast, scale measures are better because they capture the degree of international activities.

Hennart (2011) argues that the operationalization and the measurements of the degree of multinationality do not match the theoretical arguments on the benefits of internationalization, which have been put forward in the literature for empirical testing. These measurements cannot be used to test theoretical arguments in the ability to exploit intangible assets, the ability to arbitrage, and the external and internal costs of foreignness (Hennart, 2011). In other words, there is a mismatch between theoretical arguments and measurements. 
The content validity of Sullivan's degree of internationalization composite index has been questioned by Ramaswamy, Kroeck \& Renforth (1996). Rugman \& Oh (2011) call this composite index to be simplistic, because it adds scale and scope metrics with attitudinal attributes, causing more confusion than clarification.

\subsubsection{Our analysis on the measurements of multinationality}

We use international business and tax accounting perspectives to identify two problems of scope metrics by counting the number of countries or the number of subsidiaries as proxies for the breadth or dispersion of internationalization. First, an inherent limitation of scope metrics is that they do not consider the nature of foreign subsidiaries. Specifically, MNEs often use special purpose entities (SPEs) in their ownership structures. According to OECD (2014), SPE is defined as a legal entity, formally registered with a national authority and subject to fiscal and other legal obligations in the economy in which it is resident. The SPE has few or no employees, little or no production, and little or no physical presence in the host country. Almost all the assets and liabilities of the enterprise represent investments in or from other countries. They tend to be established in low-tax jurisdictions and tax havens which are geared toward preferential tax benefits rather than engaging in value-creating activities. OECD separately compiles FDI statistics for resident SPEs (OECD, 2014). In a related manner, UNCTAD (2016) reports that FDI into tax havens and offshore financial centres (OFCs) have increased. OFCs refer to conduit jurisdictions as attractive intermediate destinations to transfer capital to other countries via the use of holding companies to manage interest payments or dividends without triggering taxation (Weyzig, 2013).

Second, there is a growing trend of US MNEs to reduce the number of subsidiaries disclosed in their 10-K filing. Donohoe, McGill \& Outslay (2012), international taxation scholars, 
surmise that media scrutiny is probably one of the drivers of the growing interests in tax havens and MNEs' tax avoidance behavior. They cite Google, which listed 108 subsidiaries in 2009 but only 2 in 2011. This trend towards opacity has continued. In 2015, a new company Alphabet was established as the parent company of Google. Alphabet lists only one subsidiary - Google (Alphabet, 2015).

Cooper (2018) provides an excellent comprehensive review on MNEs' corporate tax planning. MNEs use SPEs in their ownership structures, tax havens, offshore financial centers (OFCs) and other mechanisms and methods to reduce their tax bills within the scope of law. It is noted that the locations (e.g. tax havens, etc.) and the nature of subsidiaries (e.g. SPEs, etc.) have different impacts on performance. In summary, the scope metrics are poor proxies for the breadth and dispersion of multinationality.

\subsection{Inconsistency between conceptualization and measurements of firm performance}

\subsubsection{Literature review}

The M-P literature has used a wide variety of constructs to measure the firm's overall performance. They can broadly be grouped into financial, operational and organizational effectiveness performance (Hult, Ketchen, Griffith, Chabowski, Hamman, Dykes, Pollitte, \& Cavusgil, 2008; Li, 2007; Venkatraman \& Ramanujan, 1986). Previous studies use both accounting-based and capital market-based performance indicators. Typically, accountingbased performance indicators are built upon accounting principles and often refer to profitability ratios. These include return on sales (ROS); return on assets (ROA); return on equity (ROE). They are past-oriented (Dittfeld, 2017).

Market-based performance indicators focus on risk considerations (e.g. beta or risk-adjusted profitability ratios) and take the investor's view (e.g. Jensen's alpha; Sharpens; cumulative 
abnormal returns; market-to-book ratio; Tobin's Q; excess value/ excess Q). They are futureoriented. However, Verbeke \& Brugman (2009) argue that market-based performance indicators are a poor and inadequate proxy of true performance. Verbeke \& Brugman (2009) also criticize several studies using both accounting-based and market-based performance indicators in one study because the differences between these two types of performance are idiosyncratic for each firm.

Operational performance indicators focus on key determinants of success that might lead to financial performance (Venkatraman \& Ramanujan, 1986). According to Richter, Schmidt, Ladwig \& Wulhorst (2017), they consist of two types of outcomes: product-market outcomes (e.g. market share, new product introduction, and product quality) and internal process outcomes (e.g. efficiency, productivity, employee satisfaction and cycle time). However, we find that apart from a few exceptions ( $\mathrm{Li}, 2008)$, operational performance measures have been less used in previous M-P empirical studies.

Overall effectiveness indicators include reputation, survival, achievement of goals, and a firm's performance relative to competitors, etc. (Venkatraman \& Ramanujan, 1986). Richter et al. (2017) suggest that they are strategic in nature and can be further formulated and implemented along the firm's performance goals. However, we find that effectiveness performance indicators are seldom used in the M-P empirical research. The studies by Rugman (1983), Rugman \& Nguyen (2014) and Rugman, Nguyen \& Wei (2016) are among few exceptions which compare the performance of firms in different countries with global peers using the industry financial data.

\subsubsection{Our analysis on the accounting-based performance measurements}


We use the accounting perspective to identify some inherent limitations of accounting-based performance indicators. The calculation of accounting-based profit or loss only considers the cost of debt finance (i.e., interest expense) and its allowed tax deductibility; however, it does not account for the cost of equity capital. Furthermore, accounting-based performance indicators may be subject to managerial manipulation (Morck \& Yeung, 1991). In addition, the strict criteria of some accounting standards may affect accounting-based performance indicators. For example, under the International Accounting Standard IAS38, R\&D expenditure cannot be recognized as intangible assets, so it is expensed as incurred in the accounting period. Development costs are capitalized as intangible assets only after the technical and commercial feasibility of the asset for sale or use has been established. Similarly, corporate reputation (i.e. goodwill) cannot be valued reliably in monetary amount as generated and only purchased goodwill can be recognized as intangible assets.

However, we find that most M-P research have utilized operating profit and net profit to construct performance variables, where they are computed by subtracting selling, general administrative, advertising, promotion and marketing, $R \& D$ expenses and some other expenses from gross profits. Marketing and $R \& D$ expenses are the significant items that are subtracted from gross profit in order to compute operating profit and net profit. Meantime, M-P research also commonly uses marketing and $R \& D$ expenses over total sales as proxies for intangible asset of marketing (marketing intensity) and firm-specific technical know-how (R\&D intensity) (Kirca et al., 2011; Berry, 2006).

From an accounting perspective, marketing and $R \& D$ activities appear to reduce accountingbased profits. Thus, it becomes very difficult to compare performance among firms using operating profit and net profit. Furthermore, from a statistical point of view, statistical models trying to determine relationships between FSAs (marketing intensity and R\&D) and firm 
performance (operating profit and net profit) may have serious endogenous issues. Nevertheless, we find that many of the previous studies do not pay attention to these particularly important issues which we identify here in our analysis.

\subsection{A deficiency of studies distinguishing performance of home country operations from performance of international operations of foreign subsidiaries}

Our analysis: One of the underlying assumptions which justifies the M-P research is that a firm can attain at least the same or higher profits in foreign operations than home country operations (Contractor, 2012). Thus, we argue that it would be more logical to clearly demarcate the firm's total performance into performance of its home country operations and that of international operations of foreign subsidiaries. However, we find that many previous studies in the M-P literature focus on the firm's overall total financial performance. In the large volume of M-P research, there are only two exceptions which empirically test return on home country assets (ROHA) and return on foreign assets (ROFA) separately. These studies are Gestrin, Knight \& Rugman (1998) and Rugman, Yip, \& Jayaratnet (2008).

The studies by Fisch \& Zschoche (2011a, b, 2012) are among very few attempts examining the aggregated foreign performance of all foreign subsidiaries of German parent firms in terms of return on sales (ROS) and return on equity (ROE) using a dataset by the Central Bank of Germany having collected FDI information of German firms. They do not consider the performance of the whole groups, but the performance of the entire network of foreign subsidiaries of the groups. These four studies provide useful insights into the performance of foreign operations of MNEs.

\subsection{Neglecting some critical finance-related factors}


Our analysis: First, one of the most critical finance-related factors which have been largely neglected in the M-P literature is the risk-return trade-off in evaluating firm performance. Although early IB research as exemplified in the work of Rugman (1976) is the first to study risk reduction by international diversification, the risk-return relationship has received scant attention in subsequent M-P studies, excepting Hughes, Logue \& Sweeney (1975), Buehner (1987), Michel \& Shaked (1986), and Kim et al. (1993). Consequently, Verbeke \& Brugman (2009) sharply criticize this problem in the M-P literature.

Second, we find that the M-P literature has not considered performance measurements from the perspective of value-based management. The tenet of the value-based performance perspective is that the firm only generates wealth when the generated return exceeds the return required by both equity and debt capital providers (Martin \& Petty, 2000). Thus, measurements of economic profits (Severn \& Laurence, 1974) or economic returns, such as economic value added (EVA) (Stewart, 1991) will be more relevant. EVA is calculated by the difference between the Net Operating Profit After Tax (NOPAT) and the opportunity cost of invested capital. Shareholders gain when the return on the capital employed greater than the cost of capital (including debt and equity capital). Other value-based performance measurements, such as cash value added (CVA) and cash flow return on investment (CFROI) may also be relevant. However, they also have limitations because they focus on short-term orientation.

\subsection{Inconsistency between conceptualization and measurement of firm-specific intangible assets}

\subsubsection{Literature review}


The meta-analysis of Kirca et al. (2011) finds that many of the previous studies mainly use two proxies as measurements for intangible assets. First, $R \& D$ expense over total sales (R\&D intensity) is a proxy for technology assets, such as technological know-how and patents. Second, advertising expense over total sales (marketing intensity) is a proxy for marketing assets, such as brand name, reputation, etc. It is argued that due to the intangible character of R\&D and marketing, and the associated high transaction costs in the case of a sale to third parties, the internal use is preferable (Kirca et al., 2011). R\&D intensity and marketing intensity are also often used as moderating or control variables (Dittfeld, 2017). However, the empirical results of the moderating effects on the M-P relationship provide no consistent support for these two types of intangible assets (Kirca et al., 2011).

\subsubsection{Our analysis on measurements of intangible assets}

We analyze the inconsistency between conceptualization and measurements of firm-specific intangible assets by referring to the International Accounting Standard IAS38 on Intangible Asset for two reasons (IAS8 website, 2019). First, it provides clarity because the literature has used a wide range of definitions and measurements. Second, it provides strict accounting criteria for recognition and measurement. Examples of intangible assets are patented technology, trademarks, trade secrets, software, databases, internet domains, video and audio materials, customer base, licensing, royalty and standstill agreements, franchise agreements, marketing rights, and goodwill (IAS8 website, 2019). Intangible assets are reported in the balance sheet of the firm.

According to Lhaopadchan (2010) accounting for intangible assets is one of the most controversial and intractable issues in accounting. Much of the complexity relates to accounting for one section of intangible assets: goodwill. Goodwill is created when an asset 
or business is purchased. It relates to the value recorded for the purchase that is over the fair value of the assets acquired. Goodwill is thought to be open to management manipulation as they have considerable discretion over when its value should be reduced or written off following any impairment (Lhaopadchan, 2010). On the other hand, patents included in intangible assets are for either purchased patents or only minor portion (legal fees, application fees, etc.) of the technology that the firm has developed internally as the majority portion of $R \& D$ is expensed as incurred in the accounting period.

In our view, intangible assets can be measured directly by the ratios of intangible assets over total assets or intangible assets over total sales. However, we find that these ratios which measure true intangible assets have been seldom used in previous M-P studies. We highly recommend that future research refer to accounting principles when accounting data are used for empirical testing. Furthermore, it is important to use precise terminologies and measurements which are readily available in the fields of accounting and financial management.

Several previous studies cannot detect a moderating effect of R\&D and marketing intensity. One plausible explanation can be built upon "new" internalization theory which is an extension of "classic" internalization, emphasizing the location-boundedness and the tacit nature of FSAs as exemplified in the concepts of non-location bound NLB FSAs and location bound LB FSAs (Rugman \& Verbeke, 1992; Rugman et al., 2011; for an explanation of NLB and LB FSAs, see Appendix 1). R\&D and marketing intensity developed by parent firms in home countries are not unlimited in international transferability as the literature assumes. Indeed, Rugman \& Almodovar (2011) and Rugman \& Sukpanich (2006) show that FSAs are region-bound, i.e. they can be transferred, utilized and exploited within the home region rather than across regions. Furthermore, NLB FSAs need to be complemented by 
additional LB FSAs developed by foreign subsidiaries in host countries. The recombination of resources requires substantial investments, learning and legitimacy creation over time (Verbeke, 2013).

\subsection{The dominance of US firm datasets in the geographic research settings}

Our analysis: It is important to assess the geographic focus of previous M-P empirical studies because the contextual conditions have an impact on the nature of research findings and conclusions. By following Jormanainen \& Kovesnikov (2012), we analyze 128 empirical articles to understand geographic distribution of research contexts and datasets. We find that the number of studies using datasets of U.S. firms is predominant in the M-P literature, accounting for 52 percent of the total empirical articles. Studies using samples of firms from Europe account for 16 percent, Asia Pacific for 17 percent, and the rest of world for 15 percent. We prepare a table on the distribution of geographic research contexts and the year of publication (before versus after 2000) for 128 empirical studies used in our review. However, due to space constraints, we are not able to present it here. Overall, our finding is consistent with previous meta-analyses and literature review papers (Bausch \& Krist, 2007; Li, 2007; Kirca et al., 2011).

Studies using US firms' datasets have been dominating the M-P research for decades and it likely continues so in the future. There are three plausible explanations:

(a) Publicly listed US firms are among the largest in the world and they have a long history of internationalization with international trade and FDI activities.

(b) They are subject to rigorous requirements of financial reporting and disclosures in compliance with the US Generally Accepted Accounting Principles (US GAAP) and the filing with the US Securities and Exchange Commission (SEC). Thus, data of US firms 
become available in large databases (e.g. Compustat, Osiris, etc.). The US government, for example, BEA conduct annual survey of FDI. Data availability is an important factor in the M-P research.

(c) They tend to be examined predominantly by scholars based in US universities who actively disseminate their findings in prestigious journal outlets across disciplines.

The biased geographic focus with the dominance of US firm datasets is a problem. It limits the generalizability of the findings and reflects a limitation in the diversity of the geographic research settings (Nguyen, 2017). Glaum \& Oesterle (2007) maintain that the size of the firm's home market is one determinant influencing the firm's internationalization strategy.

\subsection{Other methodological issues}

Our analysis: Many previous studies use single country datasets, accounting for 90 percent of our sample of articles for review, and approximately 10 percent of the sample using multicountry datasets. Furthermore, there is an under-representation of cross-country comparative analysis, revealing an under-estimation of contextual factors. All previous empirical studies employ quantitative method with econometric models and regression testing techniques. They use secondary archival financial data of parent firms. There is no study which uses survey data or interviews with MNE managers.

The findings reveal several methodological limitations in terms of rigor and generalizability of the findings and conclusions of the M-P literature. First, many previous studies use archival and secondary datasets of large firms from a single country, either advanced or emerging economies may restrict the ability to reflect upon the state of the phenomenon. Second, the dominance of quantitative method and a lack of qualitative method is an inherent methodological limitation. Complementary use of survey data and interviews may provide 
useful insights from MNE managers on how they manage internationalization and firm performance. Third, we find that several previous studies use data of firms from the same home countries or the same data sources but present mixed empirical findings. The explanations for these inconsistent results are manifold (Dittfeld, 2017). These include different theoretical perspectives, an empirical examination of the performance of the whole group versus the network of foreign subsidiaries, time periods of datasets, range of industries, the wide variety of measurements, and the use of single or multiple indicators of multinationality and performance, and the inclusion of moderating effects and the set of control variables (Dittfeld, 2017).

\section{Suggestions for future research}

\subsection{Firm performance is determined by FSAs, not by the degree of multinationality}

We combine Rugman (1981) theoretical framework of firm-specific advantages (FSAs) and country-specific advantages (CSAs) built upon internalization theory in the IB literature with the accounting perspective built upon the Conceptual Framework of Financial Reporting (IFRS website, 2018) to suggest that the key determinant of a firm performance is FSAs, not the degree of multinationality. From internalization theory perspective, Rugman \& Verbeke (2008) maintain that if performance is the dependent variable, the true independent variables are FSAs (Rugman, 1981) and multinationality is an intermediate variable. FSAs can be developed anywhere in MNEs, either by parent firms and or by foreign subsidiaries by accessing and utilizing home and host CSAs, thus leading to the generation of non-location bound (NLB) and location bound (LB) FSAs (Rugman \& Verbeke, 2001; Rugman et al., 2011; Nguyen \& Rugman, 2015a, b). 
We extend Rugman \& Verbeke (2008)'s thinking by using the accounting perspective. A firm's performance is determined by the effective and efficient management of the balance sheet (assets, liabilities and equities) to deliver the results in the income and balance short and long-term objectives with a specific focus on value creation. It is important to monitor the performance of home country operations and international operations of foreign subsidiaries, which are consolidated as total performance of the parent firm (see IFRS 10 - Consolidated Financial Statements, IFRS website, 2019). In short, the determinant of a firm's performance is the managerial capabilities of development, deployment, combination, utilization and exploitation of FSAs bundles and multinationality is an intermediate mechanism.

Furthermore, we recommend that future research use other measurements for FSAs. These include the financial ratio of intangible fixed assets over total assets; the use of internal capital markets to overcome external capital market imperfections (Aggarwal \& Kyaw, 2008; Aulakh \& Mudambi, 2005; Desai, Foley \& Hines, 2004; Mudambi, 1999; Nguyen \& Rugman, 2015b; Nguyen \& Almodovar, 2018; Rugman, 1980); financial management capabilities using survey data (Nguyen \& Rugman, 2015b); human resource qualification of overall workforce and specialized human resources in R\&D (Almodóvar, Verbeke \& Rodríguez-Ruiz, 2016).

\subsection{Examine the relationship between retained earnings and reinvestments in the development, creation and generation of FSAs}

Retained earnings are a type of internal equity finance, defined as internally generated financing source within the firm by retaining profits as opposed to externally raised equities through new share issues on the stock exchanges (Nguyen \& Rugman, 2015b). Retained earnings are an important financing source according to the pecking order theory in the 
finance literature (Myers \& Majluf, 1984). In corporate finance, there are three main financing sources: internal funds (retained earnings), debt and new equity. The pecking order of capital structure postulates that firms prioritize their sources of financing, first preferring internal financing, and then debt and lastly raising new equity. Previous studies in the finance literature find financial leverage is negatively correlated with $R \& D$ due to a lack of collateral value for most $R \& D$ and reduces the scope of tangible asset-backed financing strategies (for a survey, see Hall \& Lerner, 2010). Thus, firms tend to rely on internal funds to finance R\&D.

We recommend future research examine the use of retained earnings to finance knowledgebased FSAs. Depending on the investment, financing and dividend policies, a firm may consider different investment options using its profits. One of the promising investment options is to use retained earnings to fund reinvestments in knowledge-creating activities, such as R\&D, innovation, and intangible assets, either through purchases or self-creation. This theoretical development is based upon the pecking order theory in the corporate finance literature.

Our recommendation here differs from the extant approach of the M-P literature. Thereoretically, it is unable to ascertain whether multinationality leads to performance or whether performance leads to multinationality. Statistically, the literature also raises endogeneity concerns (Bowen, 2007; Verbeke \& Brugman, 2009). We argue that from the financial management perspective, it is unrealistic to assume that a firm will reinvest all profits (performance) which it has generated from existing operations into multinationality. In contrast, there are other options, such as share repurchase, cash holdings, and investments in financial, tangible and intangible assets, etc. 


\subsection{Provide direct empirical evidence of the benefits and costs of multinationality on firm performance}

Research on the benefits and costs of multinationality at a disaggregated level is needed. For example, studies testing the arguments on internal information costs of internationalization using the model proposed by Fisch \& Zschoche (2011b) can be applied to arguments on coordination costs. In the same vein, Richter (2014) draws upon the insights of the information cost view of Casson (1999) to develop a theoretical model focusing on the costs of internationalization, specificially the economies of scale argument. Richter (2014) provides direct empirical support for a commonly applied theoretical argument whereas previous studies focus on internationalziation effects at a much aggregated level of overall profitability and allow for implied conclusions only. We recommend that future studies focus on the disaggregated approach like those of Fisch \& Zschoche (2011b) and Richter (2014) to show the direct evidence of benefits and costs of internationalization, instead of validating different prescribed functional forms of the M-P relationship.

\subsection{Use geographic segment measurements instead of traditional measurements of multinationality}

By identifying the limitation of scope metrics to measure multinationality in the findings and discussion section, we recommend that future research use geographic segment measurements instead of traditional measurements of multinationality. We also highlight the necessity to examine the nature of foreign subsidiaries in particular countries (e.g. SPEs, OFCs, tax havens, etc.) because different types of subsidiaries may have different implications for firm's total performance. Most of large firms have reported and disclosed information on geographic segments and business segments in compliance with the 
international financial reporting standard IFRS8-Operating Segments and the US GAAP FASB131-Disclosures about Segments of an Enterprise and Related Information. We suggest that future research may observe and compare a firm's performance with different levels of regional diversification (Qian et al., 2008; Nguyen, 2014) and whether operations in particular regions, for example, home regions, are more promising than in other regions.

\subsection{Consider using other alternative performance measurements, such as value-based performance measurements}

We recommend that future research consider using other alternative perforamnce measures beyond the accounting-based and market-based performance indicators. Value-based performance measurements, such as economic value added (EVA), cash value added (CVA) and cash flow return on investment (CFROI) may be relevant. The assessment of the value of a firm is based on its future prospects given that there is a growing interest in measuring shareholder value rather than earnings (Martin \& Petty, 2000). They are less distorted by accounting principles as explained in our analysis section of performance measurements.

\subsection{Demarcate a firm's total performance: distinguish performance of home country operations from performance of international operations}

On the basis of the IFRS Conceptual Framework, we recommend that future research focus on distinguishing the performance of home country operations (e.g. return on home country assets ROHA) and international operations (e.g. return on foreign assets ROFA) (Rugman et al., 2008) or aggrregrated performance of foreign subsidiaries (Fisch \& Zschoche, 2011a,b, 2012). This approach will provide a clear picture to enhance our understanding whether or not international operations generate similar or better or worse performance results than home 
country operations. It is now possible to calculate ROHA and ROFA separately as firms report these types of data (Rugman et al., 2008).

\subsection{Include finance factors in evaluating firm performance}

We suggest that future research consider risk-return trade off and the financial benchmarking method when it comes to performance evaluation, such as financial returns adjusted for risks. Financial benchmarking involves a financial analysis and compares the findings to other firms in order to assess the firm's competitiveness, productivity and efficiency. It is a frequently used method in the fields of management accounting and financial management, and it has been widely adopted by MNEs in business reality. One of the commonly used techniques is to compare the firm performance with global peers using the industry financial ratios (for a detailed discussion, see Rugman et al., 2016). It is widely used in enterprise risk management that helps firm manage risks across the enterprise, and in the specific areas of credit, market and operational risks. As such, the findings from future studies using the benchmarking method to compare the performance of the firm with global peers by focusing on the industry financial data will provide useful implications for theory and practice.

\subsection{Increase the diversity of research contexts and comparative studies}

Our study finds that the US firms are the dominant research context, which presents a critical limitation of the extant literature. In order to improve the generalizability of the research findings, a diversity of research contexts and broader geographic focus will be needed in future research. Comparative studies which compare and contrast the internationalization strategy and performance of firms from different countries and regions, and firms from advanced and emerging economies will definitely provide new insights into this research phenomenon. 


\section{Conclusion}

We integrate IB, accounting and finance perspectives in an attempt to provide a comprehensive and critical review of the M-P literature. We examine 160 articles from peerreview journals across domains of $\mathrm{IB}$, strategy, management, finance and accounting and classic books. We review theoretical foundation and provide a critical analysis of empirical literature, conceputalization and measurements of $\mathrm{M}, \mathrm{P}$, firm-specific intangible assets and M-P relationships. We identify eight theoretical and empirical issues which cause inconclusive findings and ambiguity in the literature. Ambiguity may arise from the use of a wide variety of theoretical perspectives, inconistencies between conceptualization and measurements of $\mathrm{M}, \mathrm{P}$, intangible assets, a mismatch between theoretical arguments and empirical testing, limited direct empirical evidence of the benefits and costs of internationalziation, an omission of critical finance factors in empirics (e.g. risk-return trade off in performance evaluation, etc.), neglecting of accounting principles when accounting data are used, and a lack of diversity of research text and cross-country comparative analysis. We make eight recommendations to address these eight inconsistencies, which we hope that future research will take into consideration in developing theoretical foundation and in designing empirical tests.

\section{REFERENCES}

Aabo, T., Pantzalis, C. \& Park, J-C. 2016. Multinationality as real option facilitator - Illusion or reality? Journal of Corporate Finance, 38: 1-17.

Abdi, M. \& Aulakh, P.S. 2018. Internationalization and performance: Degree, duration and scale of operations. Journal of International Business Studies, 49(7): 832-857.

Aggarwal, R., \& Kyaw, N.A. 2008. Internal capital networks as a source of MNC competitive advantage: Evidence from foreign subsidiary capital structure decisions. Research in International Business and Finance, 22(3): 409-439.

Allen, L., \& Pantzalis, C. 1996. Valuation of the operating flexibility of multinational corporations. Journal of International Business Studies, 27: 633-653.

Almodóvar, P. (2012). The international performance of standardizing and customizing Spanish firms: The M curve relationships. Multinational Business Review, 20(4), 306-330.

Almodóvar, P., \& Rugman, A. M. (2014). The M Curve and the Performance of Spanish International New Ventures. British Journal of Management, 25, S6-S23. 
Almodóvar, P., Verbeke, A., \& Rodríguez-Ruiz, Ó. (2016). The Internationalization of Small and Medium-Sized Family Enterprises: The Role of Human Asset Quality. Journal of Leadership \& Organizational Studies, 23(2), 162-174.

Alphabet Annual Report. 2015. Available at: https://www.sec.gov/cgi-bin/browseedgar?action $=$ getcompany $\&$ CIK $=0001652044 \&$ type $=\&$ date $b=\&$ owner $=$ include $\&$ count $=40$ [Accessed March 9, 2018]

Anand, J., Oriani, R., \& Vassolo, R.S. 2007. Managing a portfolio of real options. Advances in Strategic Management, 24: 275-303.

Aulakh, P.S., \& Mudambi, R. 2005. Financial resource flows in multinational enterprises: The role of external capital markets. Management International Review, 45(3): 307-325.

Bae, S.C., Park, B., \& Wang, X. 2008. Multinationality, R\&D intensity, and firm performance: Evidence from US manufacturing firms. Multinational Business Review, 16(1): 53-77.

Barney, J.B. 1991. Firm resources and sustained competitive advantage. Journal of Management, 17(1): 99-120.

Bausch, A., \& Krist, M. 2007. The effect of context-related moderators on the internationalizationperformance relationship: Evidence from meta-analysis. Management International Review, 47(3): 319-347.

Belderbos, R., Tong, T.W., Wu, S., 2014. Multinationality and downside risk: the roles of option portfolio and organization. Strategic Management Journal, 35: 88-106.

Berry, H. 2006. Shareholder valuation of foreign investment and expansion. Strategic Journal of Management, 27: 1123-1140.

Berry, H. \& Kaul, A. 2016. Replicating the multinationality-performance relationship: Is there an Scurve? Strategic Management Journal, 37: 2275-2290.

Birkinshaw, J.M. (1996). How multinational subsidiary mandates are gained and lost. Journal of International Business Studies, 27(3), 467-496.

Birkinshaw, J.M. (1997). Entrepreneurship in multinational corporations: The characteristics of subsidiary initiatives. Strategic Management Journal, 18(3), 207-229.

Bowen, H. P. 2007. The empirics of multinationality and performance. In A.M. Rugman (ed), Research in Global Strategic Management (Vol. 13): Regional Aspects of Multinationality and Performance (pp. 113-142). Oxford, UK: Emerald.

Buckley, P.J., \& Casson, M.C. 1976. The Future of Multinational Enterprise. Basingstoke and London: Macmillan.

Buckley, P.J., \& Casson, M.C. 1998. Models of the multinational enterprises. Journal of International Business Studies, 29: 539-561.

Buckley, P.J., Casson, M.C. \& Gulamhussen, M.A. 2002. Internationalisation - real options, knowledge management and the Uppsala approach. In Critical Perspectives on Internationalisation, ed. Virpi Havila, Mats Forsgren, and Hakan Hakansson, 229-261. Amsterdam: Elsevier Science Ltd.

Buehner, R. 1987. Assessing international diversification of West German corporations. Strategic Management Journal, 8(1): 25-37.

Bureau of Economic Analysis (BEA). 2019. International Survey: US Direct Investment Abroad. Explanation of the survey is available at https://www.bea.gov/surveys/diasurv [Accessed May 10, 2019].

Chartered Association of Business School (CABS). 2019. CABS Journal Guide 2015. https://charteredabs.org/academic-journal-guide-2015-view/ [Accessed Mar 7, 2018].

Cardinal, L.B., Miller, C.C., \& Palich, L.E. 2011. Breaking the cycle of iteration: Forensic failures of international diversification and firm performance research. Global Strategy Journal, 1(1-2): 175-186.

Capar, N., \& Kotabe, M. 2003. The relationship between international diversification and performance in service firms. Journal of International Business Studies, 34(4): 345-355.

Casson, M. 1999. The organization and evolution of the multinational enterprise: An information cost approach. Management International Review, 39(1): 77-121.

Cavanagh, A., Freeman, S., Kalfadellis, P., \& Herbert, K. 2017. Assigned versus assumed: Towards a contemporary, detailed understanding of subsidiary autonomy. International Business Review, $2,1168-1183$. 
Caves, R.E. 1971. International corporations: The industrial economics of foreign investment. Economica, 38 (149): 1-27.

Chandler, A. 1962. Strategy and Structure: Chapters in the History of the American Industrial Enterprise. Cambridge, MA: MIT Press.

Chartered Association of Business School Website (2019). Academi Journal Guide 2015. Available at https://charteredabs.org/academic-journal-guide-2015-view/ [Accessed May 10, 2019].

Chi, T. \& McGuire, D.J. 1996. Collaborative ventures and value of learning: Integrating the transaction cost and strategic option perspectices on the choice of market entry modes. Journal of International Business Studies, 27(2): 285-307.

Chiang, Y.C., \& Yu, T.H. (2005). The relationship between multinationality and the performance of Taiwan firms. Journal of American Academy of Business, 6(1), 130-134.

Click, R., \& Harrison, P. 2002. Does multinationality matter? Evidence of value destruction in US multinational corporations. Paper presented at the Academy of International Business annual meeting, Puerto Rico.

Cohen, K.J. 1972. Portfolio aspects of strategic planning. Journal of Business Policy, 4: 8-30.

Contractor, F.J. 2007. The evolutionary or multi-stage theory of internationalization and its relationship to the regionalization for a company. In A.M. Rugman (ed). Research in Global Strategic Management (Vol. 13): Regional Aspects of Multinationality and Performance (pp11-29). Oxford, UK: Emerald.

Contractor, F.J. 2012. Why do multinational firms exist? A theory note about the effect of multinational expansion on performance and recent methodological critiques. Global Strategy Journal, 2(4): 318-331.

Contractor, F.J., Kundu, S.K., \& Hsu, C.C. 2003. A three-stage theory of international expansion: The link between multinationality and performance in the service sector. Journal of International Business Studies, 34(1): 5-18.

Cooper, M. 2018. What drives the tax avoidance strategies of adopted by US MNEs. Understanding the heterogeneity of approaches to corporate tax planning in US multinational enterprises. Unpublished Ph.D. thesis. Henley Business School, University of Reading, the United Kingdom. Available at http://centaur.reading.ac.uk/77929/1/21026879_Cooper_thesis.pdf [Accessed May 10, 2019]

Cuervo-Cazurra, A., Maloney, M.M. \& Manrakhan, S. 2007. Causes of the difficulties in internationalization. Journal of International Business Studies, 38 (5): 709-725.

Czarnitzki, D., \& Hottenrott, H. 2011. Financial constraints: Routine versus cutting edge R\&D investment. Journal of Economics \& Management Strategy, 20(1): 121-157.

Daniels, J.D., \& Bracker, J. 1989. Profit performance: Do foreign operations make a difference? Management International Review, 29(1): 46-56.

Denis, D. J., Denis, D. K. \& Yost, K. 2002. Global Diversification, Industrial Diversification, and Firm Value. The Journal of Finance, 57(5): 1951-1979.

Desai, M.A., Foley, C.F., \& Hines, J.J.R. 2004. A multinational perspective on capital structure choice and internal capital markets. Journal of Finance, 59(6): 2451-2487.

Dittfeld, M. 2017. Multinationality and performance: A context-specific analysis for German firms. Management International Review, 57: 1-35.

Donohoe, M. McGill, A. \& Outslay, E. 2012. Through a glass darkly: What can we learn about a US multinational corporation's international operations from its financial statement disclosures? National Tax Journal, 65(4): 961-984.

Dunning, J.H. 1985. The United Kingdom. In Dunning, J.H. (ed.), Multinational Enterprises, Economic Structure and International Competitiveness. Chichester: John Wiley.

Duriau, V.J., Reger, R., \& Pfarrer, M.D. 2007. A content analysis of the content analysis literature in organization studies: Research themes, data sources, and methodological refinements. Organizational Research Methods, 10(5): 5-34.

Eden, L., \& Miller, S. 2001. Opening the black box: Multinationals and the costs of doing business abroad. Academy of Management Best Paper Proceedings.

Ferraris, A., Bresciani, S., \& Del Giudice, M. (2016). International diversification and firm performance: a four-stage model. EuroMed Journal of Business, 11(3), 362-375. 
Fernández-Olmos, M., Gargallo-Castel, A., \& Giner-Bagües, E. (2016). Internationalisation and performance in Spanish family SMEs: The W-curve. BRQ Business Research Quarterly, 19(2), 122-136.

Fisch, J.H., 2008. Internalization and internationalization under competing real options. Journal of International Management, 14: 108-123.

Fisch, J.H. \& Zschoche, M. 2011a. Do firms benefit from multinationality through production shifting? Journal of International Management, 17: 143-149.

Fisch, J.H., \& Zschoche, M. 2011b. The effects of liabilities of foreignness, economies of scale, and multinationality on firm performance: An information cost view. Schmalenbach Business Review, 3(11): 51-68.

Fisch, J.H. \& Zschoche, M. 2012. The role of operating flexibility in the expansion of international production networks. Strategic Management Journal, 33: 1540-1556.

Geleilate, J.M.G., Magnusson, P., Parente, R.C. \& Alvarado-Vargas, M.J. (2016). Home country institutional effects on the multinationality-performance relationship: a comparison between emerging and developed market multinationals. Journal of International Management, 22 (4): 380-402.

Geringer, M.J., Beamish, P.W., \& da Costa, R.C. 1989. Diversification strategy and internationalization: Implications for MNE performance. Strategic Management Journal, 10(2): 109-119.

Gestrin, M., Knight, R., \& Rugman, A.M. 1998. The Templeton Global Performance Index. The Oxford Executive Research Briefings: Templeton College.

Glaum, M., \& Oesterle, M-J. 2007. Forty years of research on internationalization and firm performance: More questions than answers? Management International Review, 47(3): 307317, Focused Issue.

Gomes, L., \& Ramaswany, K. 1999. An empirical examination of the form of the relationship between multinationality and performance. Journal of International Business Studies, 30(1): 173-188.

Guisinger, S. 2001. From OLI to OLMA: Incorporating higher levels of environmental and structural complexity into eclectic paradigm. International Journal of the Economics of Business, 8 (2): 257-272.

Hall, B.H. \& Lerner, 2010. The financing of R\&D and innovation. In Hall, B. H. and N. Rosenberg (eds.), Handbook of the Economics of Innovation, Elsevier.

Hennart, J.F. 1982. A theory of Multinational Enterprise. Ann Arbor, University of Michigan Press.

Hennart, J. F. 2007. The theoretical rationale for a multinationality-performance relationship. Management International Review, 47(3): 423-452.

Hennart, J. F. 2011. A theoretical assessment of the empirical literature on the impact of multinationality on performance. Global Strategy Journal, 1(1-2): 135 - 151.

Hitt, M.A., Hoskisson, R.E., \& Kim, H. 1997. International diversification: Effects on innovation and firm performance in product-diversified firms. Academy of Management Journal, 40(4): 767798.

Hitt, M. A., Tihanyi, L., Miller, T., \& Connelly, B. 2006. International diversification: Antecedents, outcomes, and moderators. Journal of Management, 32(6): 831-867.

Hughes, J.S., Logue, D.E., \& Sweeney, R.J. 1975. Corporate international diversification and market assigned measures of risk and diversification. Journal of Financial and Quantitative Analysis, 10(4): 627-637.

Hult, G. T. M., Ketchen, D. J., Griffith, D. A., Chabowski, B. R., Hamman, M. K., Dykes, B. J., Pollitte, W. A., \& Cavusgil, S T. 2008. An assessment of the measurement of performance in international business research. Journal of International Business Studies, 39(6): 1060-1080.

Hymer, S. H. (1960). Ph.D Thesis, MIT. The international operations of national firms: A study of direct foreign investment. (Subsequently published by Cambridge, Mass.: MIT Press under the same title in 1976).

IFRS website, 2018. Conceputal Framework for Financial Reporting. Available at https://www.ifrs.org/issued-standards/list-of-standards/conceptual-framework/[Accessed May 10, 2019]. 
IFRS webiste, 2018. IFRS8-Operating Segments. Available at www.ifrs.org/IFRSs/Documents/IFRS8en.pdf [Accessed Mar 7, 2018].

IFRS website, 2018. IFRS10 - Consolidated Financial Statements. Available at https://www.ifrs.org/issued-standards/list-of-standards/ifrs-10-consolidated-financialstatements/ [Accessed May 10, 2019].

Johanson, J., \& Vahlne, J.-E. 1977. The internationalization process of the firm: A model of knowledge development and increasing foreign market commitments. Journal of International Business Studies, 8(1): 23-32.

Johanson, J., \& Vahlne, J.-E. 2009. The Uppsala internationalization process model revisited: From liability of foreignness to liability of outsidership. Journal of International Business Studies, 40(9): 1411-1431.

Jormanainen, I., \& Koveshnikov, A. 2012. International activities of emerging market firms: A critical assessment of research in top international management journals. Management International Review, 52(5): 691-725.

Kim, W.C., Hwang, P., \& Burgers, W.P. 1993. Multinationals' diversification and risk-return tradeoff. Strategic Management Journal, 14(4): 275-286.

Kirca, A.H., Hult, T.M., Roth, K., Cavusgil, S.T., Perry, M.Z., Akdeniz, M.B., Deligonul, S.Z., Mena, Z.A., Pollitte, W.A., Hoppner, J.J., Miller, J.C., \& White, R.C. 2011. Firm specific assets, multinationality, and financial performance: A meta-analytic review and theoretical integration. Academy of Management Journal, 54(1): 47-72.

Kirca, A.H., Hult, T.M., Deligonul, S.Z.. Perry, M.Z.. \& Cavusgil, S.T. 2012. A multilevel examination of the drivers of firm multinationality: A meta analysis. Journal of Management, 38(2): 502-530.

Kirca, A.H., Roth, K., Hult, T.M., \& Cavusgil, S.T. 2012. The role of context in the multinationalityperformance relationship: A meta-analytic review. Global Strategy Journal, 2(2): 108-121.

Kogut, B. 1991. Joint ventures and the option to expand and acquire. Management Science, 37(1):1933.

Kogut, B. \& Kulatilaka, N. 1994. Operating flexibility, global manafacturing and the option value of a multinational network. Management Science, 40(1): 123-139.

Kostova, T. \& Zaheer, S. 1999. Organizational legitimacy under conditions of complexity: The case of the multinational enterprise. Academy of Management Review, 24(1): 64-81.

Kotabe, M., Srinivasan, S.S., \& Aulakh, P.S. 2002. Multinationality and firm performance: The moderating role of R\&D and marketing capabilities. Journal of International Business Studies, 33(1): 79-97.

Kudina, A., Rugman, A. M. \& Yip, G. S. 2009. Testing the link between multinationality and the return on foreign assets. Multinational Business Review, 17 (3): 123-142.

Lhaopadchan, S. (2010) Fair value accounting and intangible assets. Journal of Financial Regulation and Compliance, 18(2) pp. 120-130.

Lee, I.H. (2010). The M curve: the performance of born-regional firms from Korea. Multinational Business Review, 18(4), 1-22.

Lee, I.H. (2013). The M Curve and the multinationality-performance relationship of Korean INVs. Multinational Business Review, 21(3), 214-231.

Lee, S.-H., \& Makhija, M. 2009. Flexibility in internationalization: is it valuable during an economic crisis? Strategic Management Journal, 30: 537-555.

LePine, J. A., \& Wilcox-King, A. (2010). Editors' comments: Developing novel theoretical insight from reviews of existing theory and research. Academy of Management Review, 35(4), 506509.

Li, L. 2007. Multinationality and performance: A synthetic review and research agenda. International Journal of Management Reviews, 9(2): 117-139.

Li, L. 2008. Multinationality and technical efficiency: A neglected perspective. Management International Review, 48: 39-63.

Li, J. 2007. Real options and international strategy: A critical review. Advances in Strategic Management, 24: 67-101.

Li, J. \& Rugman, A.M. 2007. Real options and the theory of foreign direct investment. International Business Review, 16(6): 687-712. 
Lu, J.W., \& Beamish, P. 2004. International diversification and firm performance: the S-curve hypothesis. Academy of Management Journal, 47(4): 598-609.

Marano, V., Arregle, J-L, Hitt, M.A., Spadafora, E. \& van Essen, M. 2016. Home Country Institutions and the Internationalization-Performance Relationship: A Meta-Analytic Review. Journal of Management, 42(5): 1075-1110.

Markowitz, H.M. 1952. Portfolio selection. The Journal of Finance, 7(1): 77-91.

Martin, J.D., \& Petty, J.W. 2000. Value Based Management. Harvard: Harvard Business School Press.

Matysiak, L., \& Bausch, A. 2012. Antecedents of MNE performance: Blinded by the obvious in 35 years of literature. Multinational Business Review, 20(2): 178-211.

Michel, A., \& Shaked, I. 1986. Multinational corporations versus domestic corporations: Financial performance and characteristics. Journal of International Business Studies, 18(3): 89-100.

Miles, M. B., \& Huberman, M. (1994). Qualitative data analysis : An expanded sourcebook. Thousand Oaks: Sage, 2 edition.

Morck, R., \& Yeung, B. 1991. Why investors value multinationality? The Journal of Business, 64(2): $165-187$.

Mudambi, R. 1999. MNE internal capital markets and subsidiary strategic independence. International Business Review, 8(2): 197-211.

Myers, S. C., \& Majluf, N. S. 1984. Corporate financing and investment decisions when firms have information that investors do not have. Journal of Financial Economics, 13(2): 187-222.

Nguyen, Q.T.K. 2014. The regional strategies of British multinational subsidiaries in South East Asia. British Journal of Management, 25(S1): 60-76.

Nguyen, Q.T.K. 2017. Multinationality and performance literature: A critical literature review and future research agenda. Management International Review, 57(3): 311-347.

Nguyen, Q.T.K. \& Almodóvar, P. 2018. Export intensity of foreign subsidiaries of multinational enterprises: The role of trade finance availability. International Business Review, 27(1): 231245.

Nguyen, Q.T.K., \& Rugman, A.M. 2015a. Multinational subsidiary sales and performance in South East Asia. International Business Review, 24(1): 115-123.

Nguyen, Q.T.K., \& Rugman, A.M. 2015b. Internal equity financing and the performance of multinational subsidiaries in emerging economies. Journal of International Business Studies, 46(4): 468-490.

OECD. 2014. Measuring international invesment by multinational enterprises: Implementation the OECD's benchmark definition of foreign direct investment, $4^{\text {th }}$ edition. Available at https://www.oecd.org/corporate/FDI-BMD4-brochure.pdf [Accessed May 10, 2019].

Oesterle, M-J., \& Richta, H.N. 2013. Internationalization and firm performance: state of empirical research efforts and need for improved approaches. European Journal of International Management, 7(2): 204-224.

Oh, C.H., \& Contractor, F. 2014. A regional perspective on multinational expansion strategies: Reconsidering the three-stage paradigm. British Journal of Management, 25(S1): 42-59.

Podsakoff, P.M., MacKenzie, S.B., Bachrach, D.G. \& Podsakoff, N.P. 2005. The infuence of management journals in the 1980s and 1990s. Strategic Management Journal, 26, 473-488.

Qian, G., Li, L., Li, J., Qian, Z. 2008. Regional diversification and firm performance. Journal of International Business Studies, 39, 197-214.

Ramaswamy, K., Kroeck, K.G., \& Renforth, W. 1996. Measuring the degree of internationalization of a firm: A comment. Journal of International Business Studies, 27(1): 167-177.

Reeb, D.M, Kwok, C.C., \& Baek, Y.H. 1998. Systematic risk of the multinational corporation. Journal of International Business Studies, 29(2): 263-279.

Richter, N.F. 2014. Information costs in international business: Analyzing the effects of economies of scale, cultural diversity and decentralization. Management International Review, 54: 171193.

Richter, N. F., Schmidt, R., Ladwig, T. J., \& Wulhorst, F. 2017. A critical perspective on the measurement of performance in the empirical multinationality and performance literature. Critical Perspectives on International Business, 13(2): 94-118.

Rugman, A.M. 1976. Risk reduction by international diversification. Journal of International Business Studies, 7(2): 75-80. 
Rugman, A.M. 1980. Internalization theory and corporate international finance. California Management Review, 23(2): 73-79.

Rugman, A.M. 1981. Inside the Multinationals: The Economics of Internal Markets. New York: Columbia University Press.

Rugman, A. M. 1983. The comparative performance of U.S. and European multinational enterprises, 1970-1979. Management International Review, 23(2): 4-14.

Rugman, A.M. 1990. Multinationals and Canada-United States Free Trade. University of South Carolina Press, Columbia, SC.

Rugman, A.M. \& Almodóvar, P. 2011. The born global illusion and the regional nature of international business. In R. Ramamurti and N. Hashai (eds), Research in Global Strategic Management: The Future of Foreign Direct Investment: Essays in Honour of Yair Aharoni, pp. 265-283. Bingley: Emerald Group Publishing.

Rugman, A. M., \& Oh, C. H. 2010. Does the regional nature of multinationals affect the multinationality and performance relationship? International Business Review, 19(5): 479-488

Rugman, A.M., \& Oh, C.H. 2011. Methodological issues in the measurement of multinationality of U.S. firms. Multinational Business Review, 19(3): 202-212.

Rugman, A.M., \& Nguyen, Q.T.K. 2014. Modern international business theory and emerging economy multinational companies. In A. Cuervo-Cazurra \& R. Ramamurti (eds.) Understanding Multinationals from Emerging Markets (pp 53-80). Cambridge, UK: Cambridge University Press.

Rugman, A.M., \& Sukpanich, N. 2006. Firm specific advantages, intra-regional sales and performance of multinational enterprises. The International Trade Journal, 20(3): 355-382.

Rugman, A.M. \& Verbeke, A. (1992). A note on the transnational solution and the transaction cost theory of multinational strategic management. Journal of International Business Studies, 23(4): 761-772.

Rugman, A.M., \& Verbeke, A. 2001. Subsidiary-specific advantages in multinational enterprises. Strategic Management Journal, 22(3): 237-250.

Rugman, A.M., \& Verbeke, A. 2004. A perspective on regional and global strategies of multinational enterprises. Journal of International Business Studies, 35(1): 3-18.

Rugman, A.M., \& Verbeke, A. 2008. Internalization theory and its impact on the field of international business. In J.J. Boddewyn (ed.), (Research on Global Strategic Management), Vol. 14, International Business Scholarship: AIB Fellows on the First 50 Years and Beyond, (pp.155174). Bradford: Emerald Group.

Rugman, A.M., Lecraw, D.L., \& Booth, L.D. 1985. International Business: Firm and Environment. New York: McGraw-Hill.

Rugman, A.M., Nguyen, Q.T.K. \& Wei, Z. 2016. Rethinking the literature on the performance of Chinese multinational enterprises. Management and Organization Review, 12(2): 269-302.

Rugman, A.M., Verbeke, A., \& Nguyen, Q.T.K. 2011. Fifty years of international business and beyond. Management International Review, 51(6): 755-786.

Rugman, A.M., Yip, G., \& Jayaratnet, S. 2008. A note on return on foreign assets and foreign presence for UK multinationals. British Journal of Management, 19(2): 162-170.

Ruigrok, W., \& Wagner, H. 2003. Internationalization and performance: An organizational learning perspective. Management International Review, 43(1): 63-83.

Ruigrok, W., Amann, W., \& Wagner, H. 2007. The internationalization-performance relationship at Swiss firms: A test of the S-shape and extreme degrees of internationalization. Management International Review, 47(3): 349-368.

Severn, A.K. 1974. Investor evaluation of foreign and domestic risk. The Journal of Finance, 29(2): 545-550.

Severn, A.K., \& Laurence, M.M. 1974. Direct investment, research intensity, and profitability. Journal of Financial and Quantitative Analysis, 9(2): 181-190.

Stewart, G.B. III. 1991. The Quest for Value. HarperCollins.

Stinchcombe, A.L. 1965. Social structure and organizations. In J. March (Ed.), Handbook of organizations (pp.142-193). Chicago: Rand-McNally.

Sundaram, A. K. \& Black, J. S. 1992. The environment and internal organization of multinational enterprises. Academy of Management Review, 17 (4): 729-757. 
Suddaby, R., \& Greenwood, R. 2005. Rhetorical strategies of legitimacy. Administrative Science Quarterly, 50(1): 35-67.

Sullivan, D. 1994a. Measuring the degree of internationalization of a firm. Journal of International Business Studies. 25(2): 325-342.

Sullivan, D. 1994b: The "threshold of internationalization": Replication, extension, and reinterpretation. Management International Review, 34(2): 165-186.

Tan, J., \& Peng, M.W. 2003. Organizational slack and firm performance during economic transitions: two studies from an emerging economy. Strategic Management Journal, 24: 1249-1263.

Teece, D., Pisano, G., \& Shuen, A. 1997. Dynamic capabilities and strategic management. Strategic Management Journal, 18(8): 537-556

Thomas, D.E., \& Eden, L. 2004. What is the shape of the multinationality-performance relationship? Multinational Business Review, 12(1): 89-110.

Tong, T.W. \& Reuer, J.J. 2007. Real options in multinational corporations: Organizational challenges and risk implications. Journal of International Business Studies, 38(2):215-230.

Tushman, M., \& Romanelli, E. 1985. Organizational evolution: a metamorphis of convergence and reorientation. In L. Cummings and Staw, B. (eds), Research in Organizational Behavior (pp. 171-222). Greenwich: JAI Press.

UNCTAD. 2013. World Investment Report. Geneva: United Nations Conference on Trade and Development (UNCTAD).

UNCTAD (2016) World Investment Report 2016: Investor Nationality, Policy Challenges. United Nations, Geneva. Available at: http://unctad.org/en/pages/PublicationWebflyer.aspx?publicationid=1555 [Accessed March 7, 2018]

US GAAP, Financial Accounting Standard Board, FASB131 - Disclosures about Segments of an Enterprise and Related Information http://www.fasb.org/summary/stsum131.shtml [Accessed March 7, 2018].

Venkatraman, N., and Ramanujam, V. 1986. Measurement of business performance in strategy research: A comparison of approaches. Academy of Management Review, 11(4): 801-814.

Verbeke, A. 2013. International Business Strategy, Second edition. Cambridge: Cambridge University Press.

Verbeke, A., \& Brugman, P. 2009. Triple testing the quality of multinationality-performance research: An internalization theory perspective. International Business Review, 18(3): 265-275.

Verbeke, A., \& Forootan, Z.M. 2012. How good are multinationality performance (M-P) empirical studies? Global Strategy Journal, 2(4): 332-344.

Wan, W.P., \& Hoskisson, R.E. 2003. Home country environments, corporate diversification strategies and firm performance. Academy of Management Journal, 46(1): 27-45.

Welch, C., Piekkari, R., Plakoyiannaki, E., \& Paavilainen-Maentymaeki, E. 2011. Theorizing from case studies: Towards a pluralist future for international business research. Journal of International Business Studies, 42(5): 740-762.

Wernerfelt, B. 1984. The resource-based view of the firm. Strategic Management Journal, 5(2): 171180.

Weyzig, F. (2013). Tax treaty shopping: Structural determinants of Foreign Direct Investment routed through the Netherlands. International Tax and Public Finance, 20(6), 910-937.

Yang, Y., \& Driffield, N. 2012. Multinationality-performance relationship: A meta-analysis. Management International Review, 52(1): 23-47.

Zaheer, S. 1995. Overcoming the liability of foreignness. Academy of Management Journal, 38(2): 341-363. 


\begin{tabular}{|c|c|c|}
\hline No. & Publication outlets & Number of studies \\
\hline & $\begin{array}{l}\text { Disciplines: International Business, Management, Strategy, Marketing, } \\
\text { Trade, and Books }\end{array}$ & \\
\hline 1 & Journal of International Business Studies & 24 \\
\hline 2 & Management International Review & 24 \\
\hline 3 & International Business Review & 16 \\
\hline 4 & Strategic Management Journal & 11 \\
\hline 5 & Academy of Management Journal & 8 \\
\hline 6 & Multinational Business Review & 8 \\
\hline 7 & $\begin{array}{l}\text { Classic books (Hymer, 1960; Vernon, 1971; Stopford \& Well, 1972; Kumar, } \\
\text { 1984; Dunning, 1985; Rugman et al., 1985; Yoshihara, 1985) }\end{array}$ & 7 \\
\hline 8 & Journal of Business Research & 7 \\
\hline 9 & Global Strategy Journal & 6 \\
\hline 10 & Journal of International Management & 4 \\
\hline 11 & Journal of Management & 4 \\
\hline 12 & Journal of World Business & 3 \\
\hline 13 & British Journal of Management & 2 \\
\hline 14 & Journal of American Academy of Business & 2 \\
\hline 15 & Asia Pacific Journal of Management & 2 \\
\hline 16 & Research in Global Strategic Management & 1 \\
\hline 17 & International Journal of Management Reviews & 1 \\
\hline 18 & Journal of Business Venturing & 1 \\
\hline 19 & Journal of Global Marketing & 1 \\
\hline 20 & Journal of Transnational Management & 1 \\
\hline 21 & Sloan Management Review & 1 \\
\hline 22 & The Journal of Business & 1 \\
\hline 23 & Advances in International Competitive Management & 1 \\
\hline 24 & The International Journal of Organizational Analysis & 1 \\
\hline 25 & The International Trade Journal & 1 \\
\hline 26 & European Journal of International Management & 1 \\
\hline 27 & International Journal of Commerce and Management & 1 \\
\hline 28 & Journal of Korea Trade & 1 \\
\hline 29 & Schmalenbach Business Review & 1 \\
\hline 30 & Critical Perspective on International Business & 1 \\
\hline \multirow[t]{2}{*}{31} & African Journal of Business Management & 1 \\
\hline & Disciplines: Finance, Accounting, and Applied Economics & \\
\hline 32 & Journal of Finance & 3 \\
\hline 33 & Journal of Financial and Quantitative Analysis & 2 \\
\hline 34 & Corporate Finance Review & 2 \\
\hline 35 & Journal of Corporate Finance & 2 \\
\hline 36 & The Quarterly Review of Economics and Finance & 1 \\
\hline 37 & Applied Economics & 1 \\
\hline 38 & Oxford Bulletin of Economics and Statistics & 1 \\
\hline 39 & The Review of Economics and Statistics & 1 \\
\hline 40 & Applied Economics Letter & 1 \\
\hline 41 & Journal of International Financial Management and Accounting & 1 \\
\hline 42 & International Review of Financial Analysis & 1 \\
\hline 43 & Research in International Business and Finance & 1 \\
\hline \multirow[t]{2}{*}{44} & Journal of Business Finance and Accounting & 1 \\
\hline & Total & 160 \\
\hline
\end{tabular}


Appendix 1: Summary of key theories

$\begin{array}{llll}\text { Theories and } & \text { Key authors } & \text { Key arguments } & \text { Implications }\end{array}$

Frameworks

Hymer and the $\quad$ Hymer (1960) $\quad-$ An MNE is an institution for international production rather than

theory of the MNE for international exchange.

- Two major reasons why firms move beyond national boundaries:

1. Competition between firms can generate pecuniary externalities (structural market imperfection). The creation of MNE can internalize these externalities.

2. Firms employ abroad their monopolistic advantages.
- Structural market imperfections in

international context cause international

expansion.

- Firms' monopolistic advantages must outweigh disadvantages they face in competing with local firms in the country of production.

- International expansion may have a negative effect on a firm's performance due to additional costs of doing business abroad, risks and barriers in terms of the "liability of foreignness".

\begin{tabular}{|c|c|c|c|}
\hline \multirow[t]{3}{*}{$\begin{array}{l}\text { Internalization } \\
\text { theory }\end{array}$} & \multirow{3}{*}{$\begin{array}{l}\text { Buckley and Casson } \\
\text { (1976), Casson } \\
\text { (1979), Rugman } \\
\text { (1981) }\end{array}$} & - Intellectual foundation Coase transaction cost theory (1937) & $\begin{array}{l}\text { - Internalization is a paradigm for the theory of } \\
\text { the MNE }\end{array}$ \\
\hline & & $\begin{array}{l}\text { - Internalization of the intermediate markets (typically the markets } \\
\text { for intangible assets of production know-how and brands, etc.) } \\
\text { across national boundaries in face of natural market imperfections } \\
\text { (the public good characteristics of some assets, such as knowledge, } \\
\text { technology) and government-imposed market imperfection (e.g. } \\
\text { trade barriers, etc.) generate the MNE }\end{array}$ & $\begin{array}{l}\text { - Internalization is the most general theory of } \\
\text { the MNE and the role of MNE to overcome } \\
\text { market imperfections (by creating an internal } \\
\text { market within the MNE). }\end{array}$ \\
\hline & & $\begin{array}{l}\text { - Internalization can occur in response to market imperfections and } \\
\text { any types of externalities in the good and factor markets. }\end{array}$ & $\begin{array}{l}\text { - International expansion brings net benefits } \\
\text { (i.e. positive and linear multinationality (M) } \\
\text { and performance }(\mathrm{P}) \text { relationship due to } \\
\text { exploitation of existing intangible assets) }\end{array}$ \\
\hline
\end{tabular}


- Focusing on organizing international inter-dependencies: when a firm expands abroad, it will organize inter-dependencies through hierarchy, because it can organize inter-dependencies between agents located in different countries more efficiently than markets.

There are three conditions:

1. Inter-dependent agents must be located in different countries.

2. MNE must be the most efficient way to organize these interdependencies

3. The costs incurred by MNEs to organize these inter-dependencies must be lower than the benefits of doing so.

- Inter-dependencies include know-how, raw materials and components, marketing and distribution services and financial capital.
MNE expands abroad subject to the constraints which different country agents can be linked by inter-dependencies through contract rather than by the operation of markets and that the benefits of organizing these inter-dependencies exceed the costs.

\begin{tabular}{ll}
\hline Dunning's Eclectic & Dunning $(1977$ \\
Paradigm/ OLI & $1980,1981,1988$ \\
Framework & $1998,2000,2009 b)$
\end{tabular}

Framework

\section{There are 3 conditions for a firm to engage in FDI}

1. Ownership specific advantages $(\mathrm{O})$ : assets advantages $(\mathrm{Oa})$ and transaction advantages $(\mathrm{Ot})$; $\mathrm{O}$ includes firm specific knowledge advantages, management, marketing, financial skills, vertical integration, control of resources and control of markets, risk diversification

2. Location advantages (country-specific): national production functions, government controls and regulations, political risks and cultural values

3. Internalization (by MNEs): to enforce property rights and overcome other transaction costs, to reduce buyer uncertainty and to overcome government regulations
OLI determines international expansion.

A positive and linear multinationality $(\mathrm{M})$ and

performance $(\mathrm{P})$ relationship

\begin{tabular}{llll}
\hline $\begin{array}{l}\text { Uppsala model/ } \\
\text { internationalization }\end{array}$ & $\begin{array}{l}\text { Johanson and Vahlne } \\
(1977 ; 2009) ;\end{array}$ & - Intellectual foundation: Cyert and March (1963) behavioural & - Internationalization is correlated with net \\
\hline
\end{tabular}




\begin{tabular}{|c|c|c|c|}
\hline theory & $\begin{array}{l}\text { Johanson (1990); } \\
\text { Luostarinen (1979), } \\
\text { Johanson and } \\
\text { Wiedersheim Paul } \\
\text { (1975) }\end{array}$ & $\begin{array}{l}\text { theory; Aharoni's (1966) perspective on internationalization process. } \\
\text { - Stage model: a sequential, staged process contingent on the } \\
\text { incremental international market knowledge and experience. } \\
\text { - Psychic distance concept: degree to which a firm is uncertain of the } \\
\text { characteristics of a foreign market. }\end{array}$ & $\begin{array}{l}\text { administrative costs start to escalate and result } \\
\text { in a decline of performance (i.e., inverted U } \\
\text { curve) }\end{array}$ \\
\hline $\begin{array}{l}\text { Resource based } \\
\text { view of the firm }\end{array}$ & $\begin{array}{l}\text { Wernerfelt (1984), } \\
\text { Barney (1991), } \\
\text { Mahoney and } \\
\text { Paradian (1992), } \\
\text { Teece, Pisano and } \\
\text { Shuen (1997), } \\
\text { Rugman and Verbeke } \\
\text { (2002) }\end{array}$ & $\begin{array}{l}\text { - A firm's competitive advantages in its markets stem from its } \\
\text { unique resources and capabilities and they will lead to superior } \\
\text { returns. } \\
\text { - Resources and capabilities must be valuable, rare, non-imitable and } \\
\text { non-substitute. } \\
\text { - International expansion can leverage existing valuable resources } \\
\text { and can lead to development of new capabilities (knowledge and } \\
\text { technology). }\end{array}$ & $\begin{array}{l}\text { - Dynamic relationship between a firm's } \\
\text { specific resources and degree of } \\
\text { multinationality. } \\
\text { - Dynamic relationship between a firm's } \\
\text { degrees of multinationality }(\mathrm{M}) \text { and } \\
\text { performance }(\mathrm{P}) \text {. }\end{array}$ \\
\hline $\begin{array}{l}\text { Organizational } \\
\text { evolution } \\
\text { Perspectives }\end{array}$ & $\begin{array}{l}\text { Chandler (1962); } \\
\text { Tushman and } \\
\text { Romanelli (1985), } \\
\text { Nelson and Winter } \\
\text { (1982); Cantwell } \\
\text { (1989); Kogut and } \\
\text { Singh (1988); } \\
\text { Ghoshal and Westney } \\
\text { (1993) }\end{array}$ & $\begin{array}{l}\text { - International expansion is a natural stage of organizational } \\
\text { evolution (implicit). } \\
\text { - The evolution of organizational strategy and structure; innovation } \\
\text { and exploration of new knowledge. } \\
\text { - Organizational learning is an important driver for firm evolution. }\end{array}$ & $\begin{array}{l}\text { - Explanation of the pattern and trajectory of } \\
\text { growth of some types of MNEs both at home } \\
\text { and overseas. } \\
\text { - Internationalization may cause a firm to misfit } \\
\text { with its environment, which leads to lower } \\
\text { performance and prompts the firm to put more } \\
\text { efforts to fit with its environment, which } \\
\text { enhances performance; this occurs in a cyclical } \\
\text { fashion (i.e. one or multiple } S \text { curves) }\end{array}$ \\
\hline $\begin{array}{l}\text { Liability of } \\
\text { foreignness }\end{array}$ & $\begin{array}{l}\text { Hymer (1960); } \\
\text { Zaheer (1995); } \\
\text { Zaheer, S. and } \\
\text { Mosakowski, E. } \\
\text { (1997); Eden and }\end{array}$ & $\begin{array}{l}\text { - Intellectual foundation: Hymer (1960), FDI theory; agency theory. } \\
\text { - Risks, barriers, disadvantages and additional costs of operating }\end{array}$ & $\begin{array}{l}\text { - Internationalization may have a negative } \\
\text { effect on a firm's performance }\end{array}$ \\
\hline
\end{tabular}




\begin{tabular}{lll}
\hline $\begin{array}{l}\text { New internalization } \\
\text { theory }\end{array}$ & $\begin{array}{l}\text { Rugman and Verbeke } \\
(1992)\end{array}$ & $\begin{array}{l}\text { - MNE needs to balance the need for economic integration and } \\
\text { national responsiveness (Prahalad and Doz,1987), Bartlett and } \\
\text { Ghoshal, 1989) }\end{array}$
\end{tabular}

- NLB FSAs can lead to the advantages of scale, scope, and the exploitation of integration.

- LB FSA can lead to the benefits of national responsiveness.
- Levels of pressures and benefits of economic integration and national responsiveness determine MNE's structures and strategies

- Location-boundedness of FSAs in internationalization.

- Implications of FSA utilization on firm performance.

- The LB FSAs and NLB FSAs can be generated and diffused in the home operation, host operation and network of MNE subsidiaries.

\begin{tabular}{ll}
\hline Portfolio theory/ & Markowitz (1959); \\
Risk reduction by & Cohen (1972); \\
international & Severn (1974); \\
diversification & Rugman (1976)
\end{tabular}

A mathematical framework for assembling a portfolio of assets such that the expected return is maximized for a given level of risk, defined as variance. Its key insight is that an asset's risk and return should not be assessed by itself, but by how it contributes to a portfolio's overall risk and return (Markowitz, 1959).

Portfolio investments are viewed as a possibility to reduce risk by investing in unrelated markets (Markowitz, 1959; Chohen, 1972; Severn, 1974)

\begin{tabular}{lll}
\hline $\begin{array}{l}\text { Real options/ } \\
\text { operational }\end{array}$ & $\begin{array}{l}\text { Buckley \& Casson } \\
\text { flexibility/ } \\
\text { arbitrage }\end{array}$ & $\begin{array}{l}\text { To strategically benefit from uncertainty, MNEs must create real } \\
\text { options, such as the option to abandon and the option to grow, to }\end{array}$ \\
& $\begin{array}{l}\text { Gulamhussen }(2002) ; \\
\text { maintain flexibility in adjusting decisions, as well as to exercise } \\
\text { these options in response to opportunities or challenges. Real } \\
\text { options theory, which effectively conceptualizes and quantifies } \\
\text { (1996); Kogut }\end{array}$ & $\begin{array}{l}\text { the determinants of real options, has contributed to the } \\
\text { development of theories in MNEs decision making under }\end{array}$ \\
& $\begin{array}{l}\text { (1991); Kogut \& } \\
\text { Kulatilaka (1994); } \\
\text { Tong \& Reuer (2007) }\end{array}$ &
\end{tabular}

International diversification offers MNEs

significant risk reduction advantages which are not available to non-MNEs

The operations across borders lie in the managerial discretion to exercise valuable options in response to the realization of uncertain events and thus coordinate flexibly multinational activities within a network (Kogut, 1985; Kogut \& Kulatilaka, 1994; Li \& Rugman, 2007). However, coordination costs surrounding international operations can mitigate the benefits of operational flexibility (Miller \& Reuer, 1998; Tong \& Reuer, 2007). There are studies that use an option approach to strategy and typically focuses on multinationality implications on operational 
flexibility (Allen \& Pantzalis, 1996; Anand et al., 2007; Fisch, 2008; Fisch \& Zschoche, 2012; Lee

\& Makhija, 2009) or on downside risk (Belerbos

et al., 2014; Tan \& Peng, 2003), the net effect of

the degree of multinationality on the value-

relevance of corporate real option portfolios

(Aabo et al., 2016).

Source: Authors' compilation 